\title{
KINERJA BADAN KEPEGAWAIAN, PENDIDIKAN DAN PELATIHAN DAERAH KABUPATEN KOTABARU
}

\author{
Ade Hermawan; H. Bakhtiar \\ Sekolah Tinggi Ilmu Administrasi Bina Banua Banjarmasin \\ Email: stiabb08@gmail.com
}

\begin{abstract}
Abstrak: Tujuan penelitian ini untuk melihat kinerja Badan Kepegawaian, Pendidikan dan Pelatihan Daerah dengan merealisasikan visi dan misi Kabupaten Kotabaru. Metode yang digunakan dalam penelitian ini adalah metode evaluasi, yaitu suatu metode penelitian yang bertujuan melakukan penilaian terhadap kinerja Badan Kepegawaian, Pendidikan dan Pelatihan Kabupaten Kotabaru. Sumber data penelitian ini adalah sebagian Aparatur Sipil Negara yang pernah mendapatkan pelayanan dari Badan Kepegawaian, Pendidikan dan Pelatihan Kabupaten Kotabaru. Penelitian ini menggunakan analisa kualitatif yaitu mempelajari, menelaah dan menganalisa data, informasi dan fakta yang diperoleh kemudian data tersebut dibaca, dianalisa, dinterpretasikan dan diambil suatu kesimpulan. Hasil penelitian menunjukkan bahwa kinerja Badan Kepegawaian, Pendidikan dan Pelatihan Daerah Kabupaten Kotabaru dalam Penyelenggaraan pelayanan di Bidang Kepegawaian, Pendidikan dan Pelatihan kepada seluruh pegawai negeri sipil di lingkungan Pemerintah Kabupaten yang didasarkan pada indikator produktivitas, kualitas pelayanan dan akuntabilitas adalah dalam kategori Cukup baik. Kinerja Badan Kepegawaian, Pendidikan dan Pelatihan Daerah Kabupaten Kotabaru dalam Penyelenggaraan pelayanan di bidang kepegawaian, pendidikan dan pelatihan kepada seluruh pegawai negeri sipil di lingkungan Pemerintah Kabupaten Kotabaru dipengaruhi oleh faktor ketersediaan Sumber Daya Manusia (SDM) yang handal, sarana dan prasarana yang baik, anggaran yang proporsional dan memadai.
\end{abstract}

Kata Kunci: Kinerja; Badan Kepegawaian, Pendidikan dan Pelatihan

\begin{abstract}
This study purpose is looking at the staffing agent performance, Education and Regional Training by realizing Kotabaru Regency's vision and mission. The study method used is the evaluation method, which is a research method to evaluate Kotabaru Regency's staffing agent performance, Education and Regional Training. This research data source is a part of the State Civil Apparatus who have received services from Kotabaru Regency's staffing agent performance, Education and Regional Training. This research uses qualitative analysis which are learning, analyzing data, information and facts obtained then the data was read, analyzed, interpreted and decided a conclusion. The results showed that the staffing agent performance, Education and Regional Training in providing services in the staffing sector, Education and Training to all government employees in the Regency Government based on productivity indicators, service quality and accountability were in the Fairly good category. the staffing agent performance, Education and Regional Training in providing services in the staffing sector, Education and Training to all government employees in the Kotabaru Regency Government is influenced by the reliable Human Resources (HR)'s availability, good facilities and infrastructure, proportional and adequate budget.
\end{abstract}

Keywords: Performance; Staffing Agency, Education and Regional Training 


\section{PENDAHULUAN}

Badan Kepegawaian, Pendidikan dan Pelatihan Daerah Kabupaten Kotabaru (BKPPD) merupakan unsur penunjang urusan pemerintahan bidang kepegawaian, pendidikan dan pelatihan yang menjadi kewenangan Pemerintah Kabupaten kotabaru. Badan Kepegawaian, Pendidikan dan Pelatihan Daerah Kabupaten Kotabaru dipimpin oleh kepala Badan Kepegawaian, Pendidikan dan Pelatihan yang berkedudukan di bawah dan bertanggung jawab kepada Bupati melalui sekretaris daerah. Badan Kepegawaian, Pendidikan dan Pelatihan Daerah Kabupaten Kotabaru mempunyai tugas membantu Bupati dalam melekasanakan fungsi penunjang urusan pemerintahan bidang Badan Kepegawaian, Pendidikan dan Pelatihan yang menjadi kewenangan daerah.

Visi Badan Kepegawaian, Pendidikan dan Pelatihan Daerah Kabupaten Kotabaru tahun 2016-2021 adalah : "Terwujudnya Manajemen Aparatur Sipil Negara yang akuntabel dan profesional". Makna Visi Badan Kepegawaian, Pendidikan dan Pelatihan Daerah Kabupaten Kotabaru periode 6 tahun ke depan yaitu : Pertama : Terwujudnya Manajemen Aparatur Sipil Negara yang Akutabel, dalam hal ini BKPPD Kabupaten Kotabaru akan mewujudkan dan meningkatkan pengelolaan manajemen ASN yang Akuntabel artinya dapat dipertanggung jawabkan, dalam pengelola manajemen kepegawaian mulai dari pengadaan pegawai, penempatan, pengembangan karir, pemberian penghargaan dan hukuman, pemindahan, hingga pensiun dapat dipertanggungjawabkan. BKPPD dalam hal ini tidak diskriminatif dalam memberikan pelayanan dan meningkatkan pelayanan prima kepada PNS dalam proses manajemen kepegawaian, Kedua : Terwujudnya Aparatur Pemerintah Daerah yang Profesional yaitu kualitas aparatur pemerintah yang kompetitif, jujur, loyal, berdedikasi, berprilaku disiplin dan bertanggungjawab serta berkemampuan dalam melaksanakan tugas tugas pembangunan.

Guna mendukung pencapaian visi tersebut di atas ditetapkan misi yaitu Peningkatan Kualitas Sumber Daya Manusia Aparatur dan Peningkatan Pelayanan Administrasi Kepegawaian yang Transparan dan Akuntabel. Adapun tujuan Badan Kepegawaian, Pendidikan dan Pelatihan Daerah Kabupaten Kotabaru adalah Meningkatkan Kinerja Aparatur Sipil Negara dan Meningkatkan Pelayanan Administrasi Kepegawaian Yang Transparan Dan Akuntabel.

Guna merealisasikan visi dan misi tersebut maka diperlukan Kinerja organisasi yang baik dalam hal ini adalah kinerja Badan Kepegawaian, Pendidikan dan Pelatihan Daerah Kabupaten Kotabaru. Atas dasar itulah yang membuat peneliti tertarik untuk meneliti masalah Kinerja Badan Kepegawaian, Pendidikan dan Pelatihan Daerah Kabupaten Kotabaru.

\section{LANDASAN TEORITIS}

Kinerja adalah tingkat pencapaian pelaksanaan suatu kegiatan atau program atau kebijakan dalam mewujudkan sasaran, tujuan, misi, dan visi organisasi yang tertuang dalam rencana strategi suatu organisasi. Pernyataan tentang visi dan misi yang jelas harus sesuai dengan budaya dan kebutuhan organisasi dan kebutuhan pasar, sehingga dapat menumbuhkan komitmen pegawai terhadap perkerjaan dan memupuk semangat kerja 
pegawai, menumbuhkan rasa keharmonisan di dalam kerja pegawai dan menumbuhkan standar kerja yang prima.

Banyak faktor yang dapat berperan menciptakan kinerja, di antarannya visi dan misi, struktur organisasi, prosedur kerja, system insentif, disiplin, kerja sama, kepemimpinan dan lain-lain. Menurut Robbins (2001:248) tingkat potensial kinerja suatu kelompok bergantung pada sumber daya yang dibawa masing-masing anggota kelompok. Sumber daya yang dimaksud adalah: kemampuan dan karakteristik kepribadian.

Menurut Keban (2003:25) kinerja organisasi adalah pencapaian hasil atau degree of accomplishtment. Hal ini berarti bahwa, kinerja suatu organisasi itu dapat dilihat dari tingkatan sejauh mana organisasi dapat mencapai tujuan yang didasarkan pada tujuan yang sudah ditetapkan sebelumnya. Menurut Dwiyanto (2003:32) kesulitan dalam pengukuran kinerja organisasi pelayanan publik karena tujuan dan misi organisasi publik seringkali bukan hanya kabur akan tetapi juga bersifat multidimensional.

Namun ada beberapa indikator yang biasanya digunakan untuk mengukur kinerja birokrasi publik Dwiyanto (2003:35) yaitu sebagai berikut:

1. Produktifitas, Konsep produktivitas tidak hanya mengukur tingkat efisiensi, tetapi juga efektivitas pelayanan. Produktivitas pada umumnya dipahami sebagai rasio antara input dengan output.

2. Kualitas Pelayanan, Kepuasan masyarakat bisa menjadi parameter untuk menilai kinerja organisasi public.

3. Responsivitas, adalah kemampuan organisasi untuk mengenali kebutuhan masyarakat menyusun agenda dan prioritas pelayanan dan mengembangkan program-program pelayanan publik sesuai dengan kebutuhan dan aspirasi masyarakat.

4. Responsibilitas menjelaskan apakah pelaksanaan kegiatan organisasi publik itu dilakukan sesuai dengan prinsip-prinsip administrasi yang benar atau sesuai dengan kebijakan organisasi, baik yang eksplisit maupun implicit.

5. Akuntabilitas publik menunjukan pada seberapa besar kebijakan dan kegiatan organisasi publik tunduk pada para pejabat politik yang dipilih oleh rakyat, asumsinya adalah bahwa para pejabat politik tersebut karena dipilih oleh rakyat, dengan sendirinya akan selalu merepresentasikan kepentingan rakyat.

Indikator di atas menjadi ukuran bagaimana kinerja birokrasi khususnya pada Pemerintah Daerah Kabupaten Kotabaru dinilai berhasil atau sebaliknya. Menurut Rohman \& Hardianto (2019: 53 \& 55) bahwa keberhasilan yang diukur dengan beberapa indikator sebaiknya tidak hanya dilakukan secara kuantitatif, namun juga perlu dinilai dari sisi kualitatif sehingga penilaian tersebut benar-benar memberikan umpan balik bagi perbaikan dan peningkatan kinerja selanjutnya.

\section{METODE PENELITIAN}

Metode yang dipergunakan dalam penelitian ini adalah metode evaluasi, yaitu suatu metoda penelitian yang bertujuan guna melakukan penilaian terhadap Kinerja Badan Kepegawaian, Pendidikan dan Pelatihan Kabupaten Kotabaru. Sumber data dalam penelitian 
ini adalah sebagian Aparatur Sipil Negara yang pernah mendapatkan pelayanan dari Badan Kepegawaian, Pendidikan dan Pelatihan Kabupaten Kotabaru yang mempunyai pengetahuan dan informasi mengenai kinerja Badan Kepegawaian, Pendidikan dan Pelatihan Kabupaten Kotabaru selama periode waktu penelitian ini dilakukan. Data atau informasi yang diperlukan adalah gambaran umum Badan Kepegawaian, Pendidikan dan Pelatihan Kabupaten Kotabaru, Produktivitas Badan Kepegawaian, Pendidikan dan Pelatihan Kabupaten Kotabaru, Kualitas pelayanan Badan Kepegawaian, Pendidikan dan Pelatihan Kabupaten Kotabaru, dan Akuntabilitas Badan Kepegawaian, Pendidikan dan Pelatihan Kabupaten Kotabaru. Teknik pengumpulan data yang dipergunakan dalam penelitian ini adalah: kuisioner dan dokumentasi. Peneliti menyebarkan angket untuk memperoleh data yang sesuai dengan masalah atau persoalan yang akan diteliti. Dan Melakukan pengumpulan data-data sekunder yang ada pada Badan Kepegawaian, Pendidikan dan Pelatihan Kabupaten Kotabaru (Suharsimi, 2002, Sugiyono, 2007, Moleong, 2009). Peneliti menggunakan analisa kualitatif yaitu mempelajari, menelaah dan menganalisa data, informasi dan fakta yang penulis peroleh kemudian data tersebut dibaca, dianalisa dan dinterpretasikan untuk akhirnya diambil suatu kesimpulan (Miles \& Huberman, 2007). Difinisi operasional variabel Kinerja dalam penelitian ini adalah Prestasi atau hasil kerja yang dicapai Badan Kepegawaian, Pendidikan dan Pelatihan Kabupaten Kotabaru dalam pelaksanaan pelayanan kepada pegawai negeri sipil di Kabupaten Kotabaru produktivitas yang diukur dengan indikator : produktivitas, kualitas pelayanan, dan akuntabilitas Badan Kepegawaian, Pendidikan dan Pelatihan Kabupaten Kotabaru dalam melaksanakan tugas dan fungsinya yaitu dalam memberikan pelayanan kepegawaian kepada Pegawai negeri sipil di lingkungan pemerintah Kotabaru.

\section{HASIL DAN PEMBAHASAN}

Berdasarkan data sekunder yang berhasil peneliti peroleh di lapangan maka diperoleh Hasil penelitian berupa gambaran Badan Kepegawaian Pendidikan dan Pelatihan Daerah Kabupaten Kotabaru sebagaimana yang tersaji dalam uraian berikut ini.

Penyelenggaraan pelayanan Badan Kepegawaian Pendidikan dan Pelatihan Daerah pada saat ini adalah melaksanakan fungsi sebagai Lembaga Teknis, yang melaksanakan tugas pokok dan fungsinya, berdasarkan Peraturan Daerah Kabupaten Kotabaru No. 21 Tahun 2016 tentang Pembentukan dan Susunan Perangkat Daerah Kabupaten Kotabaru serta Peraturan Bupati Kotabaru No. 60 Tahun 2016 tentang Kedudukan, Susunan Organisasi, Tugas Pokok dan Fungsi serta Tata Kerja Badan Kepegawaian, Pendidikan dan Pelatihan Daerah Kabupaten Kotabaru.

Sebagaimana termuat dalam Peraturan Bupati Kotabaru Nomor 60 tahun 2016 tentang Kedudukan, Susunan Organisasi, Tugas Pokok dan Fungsi, serta Tata Kerja Badan Kepegawaian, Pendidikan dan Pelatihan Daerah Kabupaten Kotabaru

Badan Kepegawaian, Pendidikan dan Pelatihan Daerah Kabupaten Kotabaru mempunyai tugas melaksanakan urusan pemerintahan daerah di bidang kepegawaian, pendidikan dan pelatihan berdasarkan asas otonomi dan tugas pembantuan.

Badan Kepegawaian, Pendidikan dan Pelatihan Daerah dalam melaksanakan tugas menyelenggarakan fungsi : 
1. Perencanaan dan penetapan kebijakan teknis di bidang kepegawaian, pendidikan dan pelatihan;

2. Penyelenggaraan urusan pemerintahan dan pelayanan umum di bidang kepegawaian, pendidikan dan pelatihan;

3. Penyelenggaraan, pengkoordinasian dan pengevaluasian kinerja pelaksanaan program/ kegiatan di bidang pengadaan, pemberhentian dan informasi;

4. Penyelenggaraan, pengkoordinasian dan pengevaluasian kinerja pelaksanaan program/ kegiatan di bidang mutasi dan promosi;

5. Penyelenggaraan, pengkoordinasian dan pengevaluasian kinerja pelaksanaan program/ kegiatan di bidang pengembangan kompetensi aparatur;

6. Penyelenggaraan, pengkoordinasian dan pengevaluasian kinerja pelaksanaan program/ kegiatan di bidang penilaian kinerja aparatur;

7. Penyelenggaraan pelaksanaan evaluasi dan pelaporan Badan Kepegawaian, Pendidikan dan Pelatihan;

8. Penyelenggaraan pelaksanaan administrasi Badan sesuai dengan Lingkup tugasnya;

9. Penyelenggaraan, pengkoordinasian dan pengevaluasian kinerja pelaksanaan program/ kegiatan di UPT;

10. Penyelenggara pelaksanaan fungsi lain yang diberikan Bupati terkait dengan tugas dan fungsinya;

Susunan Organisasi Badan Kepegawaian, Pendidikan dan Pelatihan Daerah Kabupaten Kotabaru terdiri dari:

1. Badan Kepegawaian, Pendidikan dan Pelatihan;

2. Sekretariat terdiri dari:

a. Sub Bagian Perencanaan;

b. Sub Bagian Keuangan;

c. Sub Bagian Umum dan Kepegawaian

3. Bidang Pengadaan Pemberhentian dan Informasi terdiri dari:
a. Sub Bidang Pengadaan dan pemberhentian;
b. Sub Bidang Data dan Informasi;
c. Sub Bidang Fasilitasi dan Profesi ASN;

4. Bidang Mutasi dan Informasi terdiri dari:
a. Sub Bidang Mutasi;
b. Sub Bidang Kepangkatan;
c. Sub Bidang Pengembangan Karir dan Promosi;

5. Bidang Pengembangan Kompetensi Aparatur terdiri dari:
a. Sub Bidang Diklat Penjenjangan dan Sertifikasi;
b. Sub Bidang Diklat Teknis dan Fungsional;
c. Sub Bidang Pengembangan Kompetensi;

6. Bidang Penilaian Kinerja Aparatur dan Penghargaan terdiri dari:

a. Sub Bidang Penilaian dan Evaluasi Kinerja Aparatur 1;

b. Sub Bidang Penilaian dan Evaluasi Kinerja Aparatur II; 
c. Sub Bidang Pembinaan dan Penghargaan;

7. Unit Pelaksana Teknis;

8. Kelompok Jabatan Fungsional;

Jumlah pegawai pada Badan Kepegawaian, Pendidikan dan Pelatihan Daerah Kabupaten Kotabaru keadaan sampai dengan Oktober 2019 sebanyak 50 orang terdiri dari 41 orang berstatus PNS, 9 orang berstatus Non PNS dengan rincian 6 orang JFU, 3 orang Satpam.

Keadaan pegawai Badan Kepegawaian, Pendidikan dan Pelatihan Daerah Kabupaten Kotabaru berdasarkan golongan kepangkatan terdiri dari golongan IV sebanyak 6 orang, golongan III sebanyak 23 orang, golongan II sebanyak 11 orang, dan golongan I sebanyak 1 orang.

Keadaan pegawai Badan Kepegawaian, Pendidikan dan Pelatihan Daerah Kabupaten Kotabaru berdasarkan pendidikan terdiri dari pendidikan S2 sebanyak 8 orang, pendidikan S1 sebanyak 19 orang, pendidikan diploma sebanyak 2 orang, pendidikan SLTA sebanyak 11 orang, pendidikan SD sebanyak 1 orang.

Dalam penelitian ini kinerja Badan Kepegawaian, Pendidikan dan Pelatihan Daerah Kabupaten Kotabaru, diukur dengan menggunakan tiga indikator, yaitu produktivitas, kualitas pelayanan, dan akuntabilitas pelayanan kepegawaian, pendidikan dan pelatihan yang diselenggarakan oleh Badan Kepegawaian, Pendidikan dan Pelatihan Daerah Kabupaten Kotabaru. Artinya kinerja Badan Kepegawaian, Pendidikan dan Pelatihan Daerah Kabupaten Kotabaru dapat diketahui dari Produktivitas, kualitas pelayanan dan akuntabilitas Badan Kepegawaian, Pendidikan dan Pelatihan Daerah Kabupaten Kotabaru dalam menjalankan tugas pokok dan fungsinya, yaitu menjalankan pelayanan di bidang kepegawaian, pendidikan dan pelatihan kepada seluruh pegawai negeri sipil di lingkungan Pemerintah Kabupaten Kotabaru.

Berdasarkan data primer yang berhasil peneliti kumpulkan dan peneliti olah maka hasil dan analisa penelitian mengenai kinerja Badan Kepegawaian, Pendidikan dan Pelatihan Daerah Kabupaten Kotabaru tersaji dalam uraian berikut ini.

1. Produktifitas

Produktivitas Badan Kepegawaian, Pendidikan dan Pelatihan Daerah Kabupaten Kotabaru diukur dengan indikator kemampuan organisasi dalam menjalankan pelayanan di bidang kepegawaian, pendidikan dan pelatihan kepada seluruh pegawai negeri sipil di lingkungan Pemerintah Kabupaten Kotabaru.

\section{Tabel 1. Produktivitas Pelayanan}

\begin{tabular}{|l|l|c|c|}
\hline No. & \multicolumn{1}{|c|}{ Produktivitas } & Frekuensi & Persentase \\
\hline 1. & Produktif & 10 & 25 \\
2. & Cukup produktif & 29 & 72,5 \\
3. & Tidak produktif & 1 & 2,5 \\
\hline \multicolumn{2}{r|}{ Jumlah } & 40 & 100 \\
\hline
\end{tabular}

Sumber: diolah peneliti, 2020 
Tabel 1 menunjukkan produktivitas Penyelenggaraan pelayanan di bidang kepegawaian, pendidikan dan pelatihan kepada seluruh pegawai negeri sipil di lingkungan Pemerintah Kabupaten Kotabaru. Dari 40 orang responden 10 orang menyatakan produktif, 29 orang menyatakan cukup produktif, dan 1 orang menyatakan tidak produktif. Artinya terdapat kecenderungan bahwa produktivitas Badan Kepegawaian, Pendidikan dan Pelatihan Daerah Kabupaten Kotabaru dalam Penyelenggaraan pelayanan di bidang kepegawaian, pendidikan dan pelatihan kepada seluruh pegawai negeri sipil di lingkungan Pemerintah Kabupaten Kotabaru adalah cukup produktif.

Cukup produktifnya Badan Kepegawaian, Pendidikan dan Pelatihan Daerah Kabupaten Kotabaru dibuktikan dengan pelayanan administrasi kepegawaian yang diberikan oleh Badan Kepegawaian, Pendidikan dan Pelatihan Daerah Kabupaten Kotabaru kepada para pegawai di lingkungan pemerintah daerah yang meliputi pelayanan pengadaan pegawai, penempatan pegawai, pengembangan pegawai dan pemberhentian pegawai dapat diselesaikan sebesar $70 \%$ dari seluruh target pelayanan administrasi kepegawaian yang telah diprogramkan. Adapun faktor yang menyebabkan pelayanan administrasi kepegawaian tidak dapat mencapai target $100 \%$ karena beban kerja yang dimiliki oleh Badan Kepegawaian, Pendidikan dan Pelatihan Daerah Kabupaten Kotabaru terlalu besar baik dari jenis pelayanan yang diberikan serta jumlah pegawai yang harus dilayani, disamping itu kualitas dan kuantitas pegawai Badan Kepegawaian, Pendidikan dan Pelatihan Daerah Kabupaten Kotabaru masih kurang memadai.

2. Kualitas Pelayanan

Kualitas Pelayanan Badan Kepegawaian, Pendidikan dan Pelatihan Daerah Kabupaten Kotabaru diukur dengan indikator kemampuan organisasi dalam menyelenggarakan pelayanan di bidang kepegawaian, pendidikan dan pelatihan kepada seluruh pegawai negeri sipil di lingkungan Pemerintah Kabupaten Kotabaru.

Tabel 2. Kualitas Pelayanan

\begin{tabular}{|l|l|c|c|}
\hline No. & \multicolumn{1}{|c|}{ Kualitas Pelayanan } & Frekuensi & Persentase \\
\hline 1. & Berkualitas & 10 & 25 \\
2. & Cukup berkualitas & 29 & 72,5 \\
3. & Tidak berkualitas & 1 & 2,5 \\
\hline \multicolumn{2}{r|}{ Jumlah } & 40 & 100 \\
\hline
\end{tabular}

Sumber: diolah peneliti, 2020

Tabel 2 menunjukkan kualitas pelayanan di bidang kepegawaian, pendidikan dan pelatihan kepada seluruh pegawai negeri sipil di lingkungan Pemerintah Kabupaten Kotabaru. Dari 40 orang responden 10 orang menyatakan berkualitas, 29 orang menyatakan cukup berkualitas, dan 1 orang menyatakan tidak berkualitas. Artinya terdapat kecenderungan bahwa Penyelenggaraan pelayanan di bidang kepegawaian, pendidikan dan pelatihan kepada seluruh pegawai negeri sipil di lingkungan Pemerintah Kabupaten Kotabaru adalah cukup berkualitas. 
Cukup berkualitasnya pelayanan Badan Kepegawaian, Pendidikan dan Pelatihan Daerah Kabupaten Kotabaru dibuktikan dengan pelayanan administrasi kepegawaian yang diberikan oleh Badan Kepegawaian, Pendidikan dan Pelatihan Daerah Kabupaten Kotabaru kepada para pegawai di lingkungan pemerintah daerah yang meliputi pelayanan pengadaan pegawai, penempatan pegawai, pengembangan pegawai dan pemberhentian pegawai menurut persepsi mayoritas pegawai adalah cukup memuaskan. Adapun faktor yang menyebabkan kualitas pelayanan administrasi kepegawaian tidak dapat mencapai target $100 \%$ karena kurangnya kompetensi pegawai Badan Kepegawaian, Pendidikan dan Pelatihan Daerah Kabupaten Kotabaru, kuantitas pegawai Badan Kepegawaian, Pendidikan dan Pelatihan Daerah Kabupaten Kotabaru masih kurang memadai, serta sarana kerja yang berupa teknologi informasi yang seringkali mengalami gangguan seperti koneksi internet, kerusakan software dan hardware, dan lain-lain.

3. Akuntabilitas

Akuntabilitas Badan Kepegawaian, Pendidikan dan Pelatihan Daerah Kabupaten Kotabaru diukur dengan indikator kemampuan organisasi dalam menyelenggarakan pelayanan di bidang kepegawaian, pendidikan dan pelatihan kepada seluruh pegawai negeri sipil di lingkungan Pemerintah Kabupaten Kotabaru.

\section{Tabel 3. Akuntabilitas Pelayanan}

\begin{tabular}{|l|l|c|c|}
\hline No. & \multicolumn{1}{|c|}{ Akuntabilitas } & Frekuensi & Persentase \\
\hline 1. & Akuntabel & 10 & 25 \\
2. & Cukup Akuntabel & 29 & 72,5 \\
3. & Tidak akuntabel & 1 & 2,5 \\
\hline \multicolumn{2}{r|}{ Jumlah } & 40 & 100 \\
\hline
\end{tabular}

Sumber: diolah peneliti, 2020

Tabel 3 menunjukkan Akuntabilitas Penyelenggaraan Badan Kepegawaian, Pendidikan dan Pelatihan Daerah Kabupaten Kotabaru. Dari 40 orang responden 10 orang menyatakan akuntabel, 29 orang menyatakan cukup akuntabel, dan 1 orang menyatakan tidak akuntabel. Artinya terdapat kecenderungan bahwa Penyelenggaraan pelayanan di bidang kepegawaian, pendidikan dan pelatihan kepada seluruh pegawai negeri sipil di lingkungan Pemerintah Kabupaten Kotabaru adalah cukup akuntabel.

Cukup akuntabelnya pelaksanaan tugas dan fungsi Badan Kepegawaian, Pendidikan dan Pelatihan Daerah Kabupaten Kotabaru dibuktikan dengan mayoritas pekerjaan Badan Kepegawaian, Pendidikan dan Pelatihan Daerah Kabupaten Kotabaru dalam memberikan pelayanan kepada para pegawai di lingkungan pemerintah daerah Kotabaru yang meliputi pekerjaan pelayanan pengadaan pegawai, penempatan pegawai, pengembangan pegawai dan pemberhentian pegawai menurut persepsi mayoritas pegawai adalah cukup akuntabel. Adapun faktor yang menyebabkan akuntabilitas pelaksanaan pekerjaan pelayanan administrasi kepegawaian tidak dapat mencapai target $100 \%$ karena target waktu penyelesaian pekerjaan yang terlalu singkat yang tidak sebanding dengan beban kerja yang sangat banyak. Semakin rumitnya peraturan mengenai pertanggungjawaban 
keuangan pelaksanaan pendidikan dan pelatihan pegawai membuat kinerja Badan Kepegawaian, Pendidikan dan Pelatihan Daerah Kabupaten Kotabaru menjadi kurang optimal.

Berdasarkan hasil observasi yang peneliti lakukan mengenai faktor-faktor yang dapat meningkatkan kinerja Badan Kepegawaian, Pendidikan dan Pelatihan Daerah Kabupaten Kotabaru dapat dianalisa sebagaimana uraian berikut ini.

Penyelenggaraan pelayanan di bidang kepegawaian, pendidikan dan pelatihan kepada seluruh pegawai negeri sipil di lingkungan Pemerintah Kabupaten sangat dipengaruhi oleh beberapa faktor, diantaranya ketersediaan Sumber Daya Manusia (SDM) yang handal, sarana dan prasarana, anggaran yang proporsional dan memadai.

1. Sumber Daya Manusia (SDM) yang handal

Sebagaimana Gambaran umum kondisi Jumlah PNS Badan Kepegawaian Pendidikan dan Pelatihan Daerah dari Jumlah PNS di Pemkab Kotabaru menurut keadaan Desember 2019, yaitu dimana Jumlah PNS di BKPPD tercatat sebanyak 45 PNS dan 9 orang THL dengan melayani 5.361 PNS sehingga rasio perbandingan antara PNS BKPPD terhadap PNS Pemkab Kotabaru 1: 99 orang, Perbadingan tersebut mengakibatkan beban pegawai BKPPD dalam melayani PNS Pemkab Kotabaru cukup besar namun hal ini tidak mengurangi kinerja BKPPD dalam hal pengelolaan manajemen Kepegawaian PNS Kabupaten Kotabaru.

2. Sarana dan Prasarana

Kinerja Pelayanan BKPPD ditinjau dari kegiatan Sistem Informasi Kepegawaian Berdasarkan Kepmendagri No.17/2000 tentang Sistem Informasi Manajemen Kepegawaian mengisyaratkan perlu adanya sistem administrasi berbasis komputer dalam pengelolaan manajemen kepegawaian dalam hal ini Simpeg.

Simpeg dimaksudkan untuk terciptanya sistem informasi yang terpadu, berdayaguna dan berhasilguna meningkatkan kegiatan administrasi kepegawaian yang tertib, teratur, sekaligus menentukan arah kebijakan tentang mekanisme koordinasi, komunikasi aliran data dan informasi melalui teknologi informasi.

Manfaat dari Simpeg ini diharapkan mampu menyajikan data dan informasi yang sangat dibutuhkan untuk pengambilan keputusan pimpinan. Saat ini kondisi Simpeg pada BKPPD kurang mendukung dengan keperluan layanan kepegawaian yang update, sehingga diperbarui dengan sistem layanan data kepegawaian yang diarahkan untuk mendukung database (system informasi) kepegawaian serta layanan data. untuk kedepannya Program Simpeg ini secara bertahap akan digantikan dengan sistem layanan data kepegawaian sebagai pengembangan dari simpeg.

3. Anggaran yang Proporsional dan Memadai

Pelayanan kepegawaian dengan memanfaatkan teknologi informasi memerlukan investasi yang cukup besar yaitu untuk membangun sistem informasi, pengembangan sistem informasi dan pemeliharaan sistem informasi seperti pembelian perangkat keras dan perangkat lunak serta honor tenaga teknologi informasi. Penyelenggaraan pendidikan dan 
pelatihan juga memerlukan biaya yang cukup besar dalam upaya menghasilkan aparatur sipil negara yang mempunyai kompetensi dan profesional dalam bekerja.

\section{KESIMPULAN}

Dengan mengacu kepada tujuan penelitian dan berdasarkan hasil dan analisis yang telah peneliti lakukan pada bab sebelumnya maka dapat ditarik kesimpulan sebagai berikut :

1. K inerja Badan Kepegawaian, Pendidikan dan Pelatihan Daerah Kabupaten Kotabaru dalam Penyelenggaraan pelayanan di bidang kepegawaian, pendidikan dan pelatihan kepada seluruh pegawai negeri sipil di lingkungan Pemerintah Kabupaten yang didasarkan pada indikator Produktivitas, kualitas pelayanan dan akuntabilitas adalah dalam kategori Cukup baik.

2. Kinerja Badan Kepegawaian, Pendidikan dan Pelatihan Daerah Kabupaten Kotabaru dalam Penyelenggaraan pelayanan di bidang kepegawaian, pendidikan dan pelatihan kepada seluruh pegawai negeri sipil di lingkungan Pemerintah Kabupaten dipengaruhi oleh faktor ketersediaan Sumber Daya Manusia (SDM) yang handal, sarana dan prasarana yang baik, anggaran yang proporsional dan memadai.

\section{DAFTAR PUSTAKA}

Arikunto, Suharsimi, 2002. Prosedur Penelitian. PT. Rineka Cipta. Jakarta

Dwiyanto, Agus, dkk. 2003. Reformasi Birokrasi Publik di Indonesia. PSKK UGM. Yogyakarta

Kepmendagri No.17/2000 tentang Sistem Informasi Manajemen Kepegawaian

Miles, Mathew. B dan A. Micheal Huberman, 2007. Analisis Data Kualitatif. University Indonesia. Jakarta

Moleong, Lexy.J. 2009. Metode Penelitian Kualitatif. PT. Remaja Rosdakarya. Bandung.

Monahan, J., Steadman, H. J., Silver, E., Appelbaum, P. S., Robbins, P. C., Mulvey, E. P., ... \& Banks, S. (2001). Rethinking risk assessment: The MacArthur study of mental disorder and violence. Oxford University Press.

Peraturan Bupati Kotabaru No. 60 Tahun 2016 tentang Kedudukan, Susunan Organisasi, Tugas Pokok dan Fungsi serta Tata Kerja Badan Kepegawaian, Pendidikan dan Pelatihan Daerah Kabupaten Kotabaru.

Peraturan Daerah Kabupaten Kotabaru No. 21 Tahun 2016 tentang Pembentukan dan Susunan Perangkat Daerah Kabupaten Kotabaru.

Rohman, A., \& Trihardianto, W. T. (2019). Reformasi Birokrasi dan Good Governance. Malang: Intrans publishing.

Sugiyono. 2007. Metode Penelitian Kualitatif dan R\&D. Alfabeta. Bandung

Yeremia, T Keban. 2004. Enam Dimensi Strategis Administrasi Publik. Gava Media. Yogyakarta. 